\title{
Effect of UV-B Solar Radiation on Plankton Community and B-Carotene of Pacific White Shrimp, Litopenaeus vannamei
}

\author{
Mamdouh Al Harbi, Sambhu Chithambaran and Adnan Salama \\ Faculty of Marine Sciences, King Abdulaziz University, Saudi Arabia \\ Sambhu@kau.edu.sa
}

\begin{abstract}
A study was conducted to assess the effect of UV-B solar radiation on plankton community, chlorophyll-A and $\beta$-carotene of pacific white shrimp, Litopenaeus vannamei cultured in HDPE liner ponds. There were control (ponds exposed to sunlight) and treatment (ponds shaded for $50 \%$ sunlight filtration) for the study and intensive shrimp culture was done in the ponds. UV-B radiation, physico-chemical parameters of pond water, Chlorophyll-A in phytoplankton and plankton community were monitored during the period. Significant $(p<0.01)$ reduction in UV-B radiation was found in treatment ponds when compared to control with an average reduction of $23.2 \%$ at surface water due to solar filtration. Among plankton, Chlorophytes and diatoms were found to be lowered in control ponds. Dinoflagellate did not show significant difference between control and treatment, whereas Cyanophyte population decreased in increased solar radiation. Chlorophyll content in phytoplankton and shrimp $\beta$-carotene was found to be increased in treatment ponds. Significant effect was noticed on plankton growth and distribution due to UV-B radiation. However, it did not influence growth of shrimp in culture ponds.

Keywords. UV-B Radiation, Phytoplankton, Chlorophyll A, $\beta$-Carotene, Pacific white shrimp, L.vannamei
\end{abstract}

\section{Introduction}

Life processes of marine primary producers are directly affected by UV radiation from the level of molecules up to that of communities (Helbling et al., 2005; Halac et al., 2014). UV$\mathrm{B}$ radiation damages biomolecules such as DNA and proteins, suppression of algal physiology and metabolism and changes in marine aquatic community structure (Jokiel, 1980; Buma et al., 1995; Rai and Mallick, 1998). Studies demonstrate deleterious effects of UV-Bradiation on the photosynthetic characteristics of phytoplankton and distribution of primary producers in aquatic system (Forster and Liining, 1996; Holzinger and Lutz, 2006). A small increase in UV-
Bexposure could significantly reduce the size of plankton populations and affect the productivity of pond ecosystem (Sinha and Hader, 2002). It has been reported that UV-B radiation causes vertical migration and mortality of zooplankton due to lack of protective pigments, (Karanas et al., 1979; Speekmann et al., 2000). Middle East and North African region has the highest levels of UV radiation on globe and the radiation causes significant effects in the dynamics of aquatic systems (Bin Mahfoodh et al., 2002). Recent observation on high levels of carotenoid deposition in shrimp hepatopancreas and lymph suggests a degree of stress is associated with high UV radiation. Considering the consequence of solar UV-Bradiation in pond ecosystem, a study was conducted to 
assess the effect of UV-Bradiation on phytoplankton community, chlorophyll and $\beta$ carotene of Pacific white shrimp, Litopenaeus vannamei an ideal candidate species for coastal aquaculture practice in the Kingdom of Saudi Arabia.

\section{Materials and Methods}

\section{Experimental Set up}

Intensive type of shrimp culture was conducted in 8 HDPE (High Density Poly Ethylene) liner ponds $\left(300 \mathrm{~m}^{2}\right)$ at KAU Fish Farm, Jeddah for a period of 98 days. There were control and treatment for the study and all of them were quadruplicated. All culture ponds were cleaned and sundried for one week prior to water culture. In order to filter solar UV radiation at $50 \%$, treatment ponds were covered with green house roofing material and it was fixed 2 meters above from pond water surface using steel poles and rope. Whereas, control ponds were kept open to receive direct sunlight throughout culture days. On day 1 of water culture, all ponds were filled $(30 \%$ of pond) with seawater and manured by applying Urea (400g), Molasses (1.5liter) and Diammonium phosphate $(200 \mathrm{~g})$ and the dose repeated on $4^{\text {th }}$ and $8^{\text {th }}$ day of culture. Pond water level increased to 60 and $100 \%$ before applying second and third dose. Two unit of aspirator aerator (1 hp) (Force-7, Acquaeco, Italy) were installed at $40 \mathrm{~cm}$ below water level with $35 \mathrm{~cm}$ angle downward in each pond. When pond water transparency reached at $60 \mathrm{~cm}$, healthy juveniles $(1.2 \mathrm{~g})$ of L.vannamei at the rate of $100 / \mathrm{m}^{2}$ were stocked in each pond (hapa survival $>95 \%$ ). A standard fish meal based pellet feed having $35 \%$ protein (NAQUA, Jeddah) was supplemented at 7:00am, 1:00 and 6:00pm daily based on a standard feed table.

\section{Estimation of Water Quality and $U V-B$ Radiation}

Water quality parameters such as temperature and dissolved oxygen were recorded daily with
YSI DO Meter (YSI Incorporated, Yellow Springs, USA). $\mathrm{pH}$ was tested with a marine portable $\mathrm{pH}$ meter (HANNA Instruments, Romania) and salinity was tested with a refractometer (ATAGO, Germany). Ammonia (unionized), nitrates $\left(\mathrm{NO}_{3}\right)$, nitrites $\left(\mathrm{NO}_{2}\right)$, orthophosphates ( $\left.\mathrm{PO}_{4}\right)$ and alkalinity (as $\mathrm{CaCO}_{3}$ ) were recorded weekly using JBL Test kit (GmbH \& Co., Germany). UV radiometer (NIST, Edmund Optics, USA) was used to record UV-B radiation on water and at bottom $(1.5 \mathrm{~m})$ of culture ponds at 6:00am, 9:00am, 12:00noon, $3: 00 \mathrm{pm}$ and $6: 00 \mathrm{pm}$ daily. Water samples from culture ponds were collected monthly for the analysis of Chlorophyll-A and plankton community. Plankton such as diatoms, dinoflagellates, Cyanophytes and Chlorophytes were identified and expressed them as Number of organisms $/ \mathrm{ml}$. Chlorophyll-A (Dawes, 1998; APHA, 1998). Total $\beta$-carotene content in shrimp meat was analyzed by the methods recommended by Kimura and Rodriguez-Amaya (2004) with slight modifications.

\section{Statistical Analysis}

One-way analysis of variance (ANOVA) was employed to find out the statistical difference in water quality parameters, chlorophyll and $\beta$ carotene in shrimp between control and treatment (Snedecor and Cochran, 1989). Linear regression analysis was done to find out the relationship between UV radiation and Chlorophyll in control and treatment ponds (Excel, 2007).

\section{Results}

\section{Physico Chemical Parameters of Pond Water}

Water quality parameters recorded during the culture period were found to be conducive for shrimp growth (Table 1).

Significant difference $(p>0.01)$ was not observed in water temperature, dissolved oxygen, $\mathrm{pH}$, transparency, ammonia, salinity, 
nitrite and calcium between control and treatment ponds; whereas, nitrate and phosphate content showed significant difference between control and treatment means.

Table 1. Water quality parameters recorded during culture period.

\begin{tabular}{|l|c|c|}
\hline \multirow{2}{*}{ Parameters } & Control & Treatment \\
\cline { 2 - 3 } & Mean \pm SD & Mean \pm SD \\
\hline Water temperature $\left({ }^{\circ} \mathrm{C}\right)^{\mathrm{NS}}$ & $32.7 \pm 0.9$ & $31.8 \pm 0.8$ \\
\hline Dissolved Oxygen $(\mathrm{ppm})^{\mathrm{NS}}$ & $4.3 \pm 0.9$ & $4.2 \pm 0.9$ \\
\hline $\mathrm{pH}^{\mathrm{NS}}$ & $7.6 \pm 0.2$ & $7.5 \pm 0.2$ \\
\hline Salinity $(\mathrm{ppt})^{\mathrm{NS}}$ & $39.6 \pm 0.3$ & $39.6 \pm 0.3$ \\
\hline Transparency $(\mathrm{cm})^{\mathrm{NS}}$ & $51.3 \pm 19.3$ & $60.6 \pm 22.4$ \\
\hline $\mathrm{NH}_{3}(\mathrm{ppm})^{\mathrm{NS}}$ & $0.02 \pm 0.0$ & $0.03 \pm 0.0$ \\
\hline $\left.\mathrm{Alkanity}^{\mathrm{N} p p m}\right)^{\mathrm{NS}}$ & $109.9 \pm 10.1$ & $111.8 \pm 7.2$ \\
\hline $\mathrm{NO}_{2}(\mathrm{ppm})^{\mathrm{NS}}$ & $0.1 \pm 0.3$ & $0.3 \pm 0.6$ \\
\hline $\mathrm{NO}_{3}(\mathrm{ppm})^{* *}$ & $0.9 \pm 0.8$ & $1.8 \pm 0.5$ \\
\hline Phosphate $(\mathrm{ppm}) * *$ & $0.5 \pm 0.6$ & $0.9 \pm 1.0$ \\
\hline Calcium $(\mathrm{ppm})^{\mathrm{NS}}$ & $427.3 \pm 55.2$ & $418.2 \pm 54.0$ \\
\hline
\end{tabular}

\section{UV-B Radiation}

Details on solar UV-B radiation recorded on water surface, pond bottom of culture ponds during culture period is depicted in Fig.1, and the mean UV-B radiation/day is shown in Fig. 2.

Significant $(p<0.01)$ reduction in UV-B radiation was noticed in treatment ponds when compared to control with an average reduction of $23.2 \%$ at surface water due to solar filtration. UV-B radiation was found to be reduced to $17.4 \%$ at pond bottom of treatment ponds when compared to control. In both control and treatment ponds, maximum UV-B radiation was recorded at 12 noon and minimum at $6 \mathrm{am}$ and $6 \mathrm{pm}$.

\section{Plankton Community}

Result on plankton analysis is presented in Fig. 3. Control ponds showed a decreased level of diatom population when compared to treatment ponds.

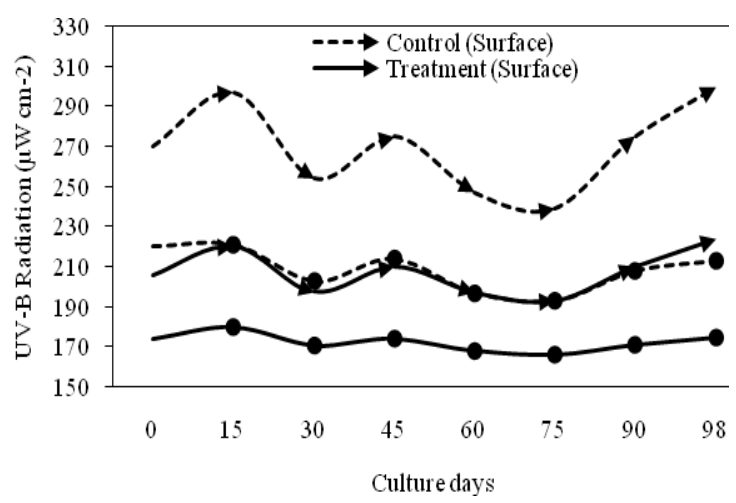

Fig.1. Mean UV-B radiation recorded during culture period.

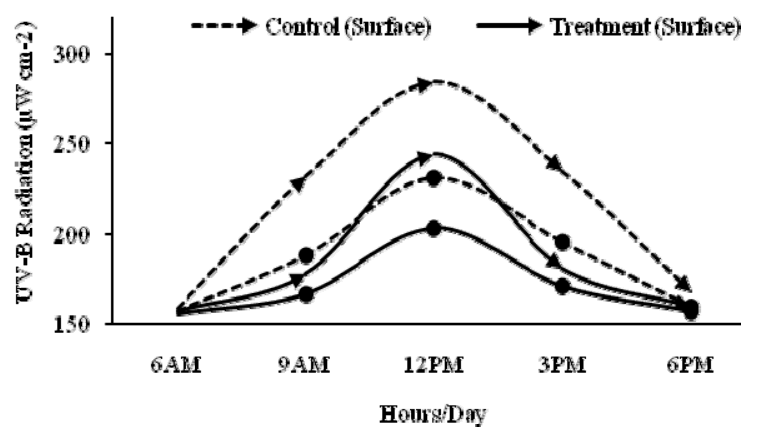

Fig.2. Mean UV-B radiation recorded in a day.

Navicula, Gyrosigma, Pleurosigma, Nitzschia, Chaetoceros and Amphora were observed in this category. Peridinium and Prorocentrum were recorded in Dinoflagellates and Oscillatoria in Cyanophytes. In both control and treatment ponds, Dinoflagellate and Cyanophyte population were found to be decreased in increasing days of culture. The Chlorophyte population was increased in control ponds, whereas it decreased in treatment ponds and Ulothrix was the major species recoded in this category.

\section{Chlorophyll-A in Phytoplankton}

Details on UV-B radiation and Chlorophyll content in control and treatment pond are presented in Fig. 4. 

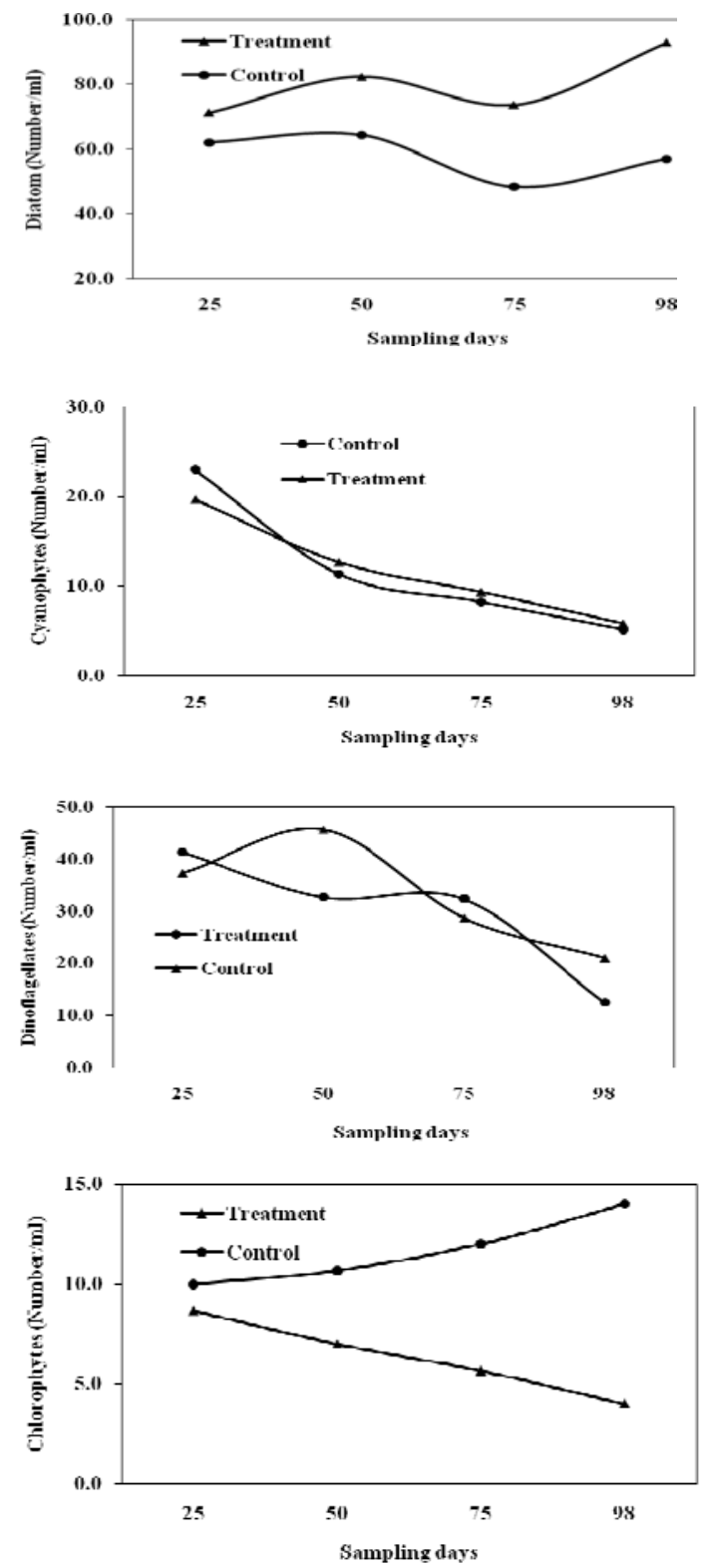

Fig. 3. Plankton community in control and treatment ponds.

Control ponds showed low chlorophyll content due to high solar UV-B radiation; whereas it increased in treatment ponds due to reduced $\mathrm{UV}-\mathrm{B}$ radiation.

Positive relationship $\left(\mathrm{R}^{2}=0.59\right)$ was found between UV-B radiation and chlorophyll in control ponds which shows that chlorophyll content is related to solar radiation (Fig. 5).

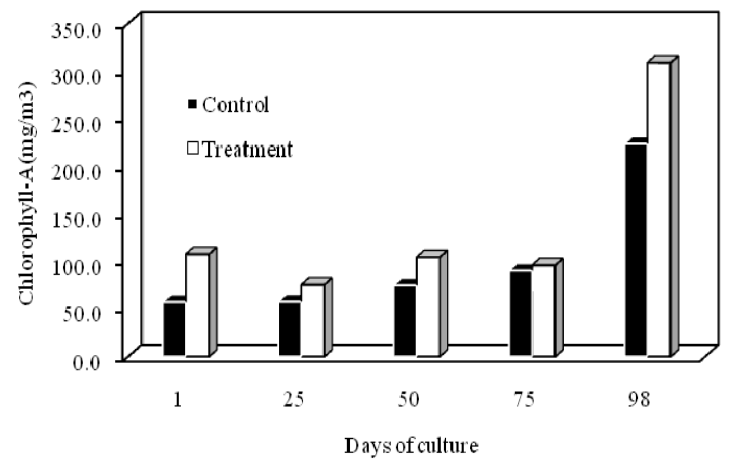

Fig.4. Chlorophyll-A in control and treatment ponds.

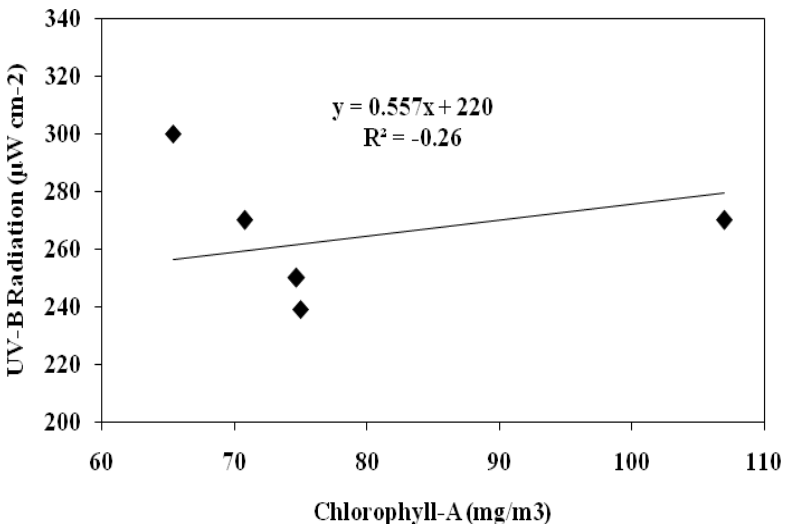

Fig.5. Linear relationship between UV-B radiation and Chlorophyll-A in control.

\section{$\beta$ - Carotene in Shrimp}

$\beta$ - Carotene content of shrimp in control and treatment pond is depicted in Fig. 6.

Shrimp grown in control pond showed low $\beta$ Carotene content when compared to treatment ponds and the observed difference was not significant $(p>0.01)$.

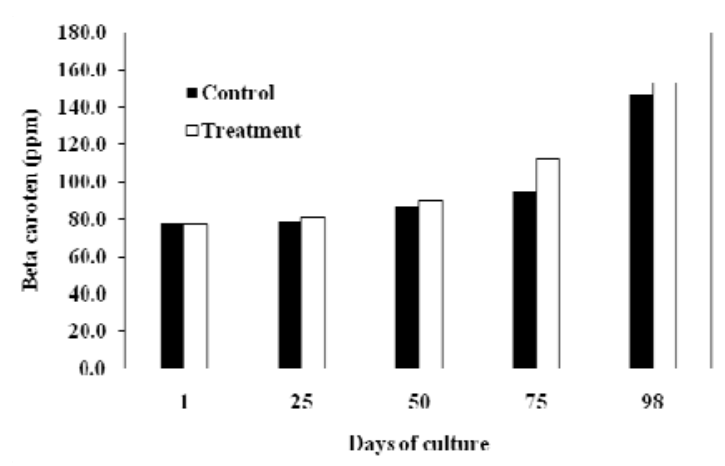

Fig.6. $\beta$ - Carotene in shrimp in control and treatment pond 


\section{Discussion}

Result of the study shows that physico chemical parameters recorded in control and treatment ponds were not influenced by UV-B radiation and these parameters were found to be within the suitable range required for shrimp growth. The enhanced nitrate and phosphate level observed in treatment ponds may be due to accumulation of nitrogenous compounds in pond water due to high shrimp biomass in the pond. According to Hader et al. (2011), with less organic matter in the upper layers of the water, UV radiation can penetrate deeper into the water and affect more complex plants and animals living there. The less UV-B radiation recorded at bottom of culture ponds may be due to the growth of algae and organic content developed due to shrimp culture in ponds.

Reports suggest that UV-B radiation has significant effect on primary production of microalgae, bleaching of photosynthetic pigments (Chlorophylls) and carotenoids and making deleterious impacts in aquatic life (Hader, 2000; Palmisano et al., 1989; Quesada and Vincent 1993; Halac et al., 2014). Result of the study indicates that reduction in UV-B radiation influences growth of planktonic organisms in culture ponds and production of beta carotene in shrimp. Hader and coworkers have extensively studied the effect of UV-B radiation on phytoplankton and its photosynthetic activity (Hader, 2000; Hader et al., 2011). According to them increased UV-B radiation seriously damages chlorophyll content and reduces the quantity in Phormidium uncinatum, Euglena gracilis, Peridinium gatunense, Anabaena variabilis, Ocillataria tenuis and Cryptomonas maculata. Results of the present study show that chlorophyll content has significant relationship to UV-B radiation. Reduction in UV-B radiation brought enhanced chlorophyll content in treatment ponds where sunlight was filtered at 50\% whereas, control ponds had low chlorophyll content in which
UV-B radiation was high due to direct solar radiation. Therefore, it is suggested that UV-B radiation has direct effect on phytoplankton community as reported by Hader (2000) and Vincent and Roy (1993).

UV-B radiation induces decreased growth rate and survival in many aquatic diatoms, Dinoflagellates, Cyanobacteria and Euglena (Ekelund, 1991. Behrenfeld et al., 1994; Davidson et al., 1994; Quesada et al., 1995; Gerber and Hader, 1992; Xue, et al., 2005). This is true in the present study also where diatomic population was lowered in high UV$\mathrm{B}$ radiation (control) ponds and it is enhanced in low radiation ponds (treatment). Cyanobacteria have been found to be highly sensitive to solar UV-B radiation, an increase in solar UV-B radiation may cause decreases in the cyanobacterial populations resulting in decreased nitrogen assimilation (Smithand Cullen, 1995). Similar reduction of Cyanophyte population was also observed in the present study. The reduction of Chlorophyte population in treatment ponds may be due to the effect of reduced sunlight received by the ponds.

According to Hader and Worrest (1991), UV B radiation bleaches carotenoid pigments of marine Cryptomonad, Cryptomonas maculata. Similar reduction in $\beta$ carotenoid and chlorophyll content was reported in marine diatoms, Ditylumbright wellii, Thalassiosira rotula and Odentella sinensis (Dohler, 1984; Sebastian et al., 1994). In the present study also $\beta$-carotene content of shrimp showed difference between control and treatments ponds being high content in low UV-B radiation ponds (treatment). This may be due to the influence of UV-B radiation as suggested by Hader and Worrest (1991).

\section{Conclusion}

Shrimp grown in treatment pond showed comparatively low growth rate when 
compared to control and the high biomass recorded in treatment ponds can be attributed to the enhanced survival rate of shrimp. Based on results, it is suggested that UV-B radiation has direct effect on growth and distribution of planktonic organisms and chlorophyll-A in culture ponds and it plays a significant role in the production of beta-carotene in shrimp body.

\section{Acknowledgements}

The authors express sincere thanks to the Dean, Faculty of Marine Sciences and Managing Director, National Aquaculture Group for the facilities and support extended for the successful completion of the study.

\section{References}

APHA. (1998) American Public Health Association, Standard Methods for the Examination of Water and Wastewater, 20th Edition. American Public Health Association, Washington D.C.

Behrenfeld, M.J., Lee, H. and Small, L.F. (1994) Interactions between nutritional status and long term responses to ultraviolet radiation stress in a marine diatom, Marine Biology, 118: 523-530.

Bin Mahfoodh, M., Al-Ayed, M.S. and Al-Dhafiri, A.M. (2002) Measurement and assessment of ultraviolet radiation in Riyadh, Saudi Arabia, International Journal of Sustainable Energy, 23 (1): 31-38.

Buma, A.G. J., Van Hannen, E.J., Roza, L., Veldhuis, M.J.W. and Gieskes, W.W.C. (1995) Monitoring ultraviolet-B-induced DNA damage in individual diatom cells by immuno-fluorescent thyrnine dimer detection, Journal of Phycology, 31: 314-321.

Dawes, C.J. (1998) Marine Botany (2nd ed). John Wiley \& Sons, USA.

Davidson, A.T., Bramich, D., Marchant, A.J. and Mcminn, A. (1994) Effect of UV-B radiation on growth and survival of Antarctic marine diatoms, Marine Biology, 119: $507-515$.

Dohler, G. (1984) Effect of UV-B radiation upon marine diatoms, Lauderua annulata and Thalassiosira rotula grown in different salinities, Marine Biology, 83: 247 253.

Ekelund, N.G.A. (1991) The effects of UV-B radiation on dinoflagellates, Journal of Plant Physiology, 138: 274278.

Excel. (2007) Microsoft Office Professional. Microsoft, USA.
Forster, R.M. and Liining, K. (1996) Photosynthetic response of Laminaria digitata to ultraviolet A and B radiation. Scientia Marina, 1: 65-71.

Gerber, S. and Hader D.P. (1992) UV effects on photosynthesis, proteins and pigmentation in the flagellate, Euglena gracilis. Biochemical and spectroscopic observations, Biochemical Systematics and Ecology, 20: 485-492.

Hader, D.P. (2000). Effects of solar UV-B radiation on aquatic ecosystems, Advances in Space Research, 26(12), 2029-2040.

Hader, D. P., Helbling, E.W., Williamson, C.E. and Worrest, R.C. (2011) Effects of UV radiation on aquatic ecosystems and interactions with climate change, Photochemical \& Photobiological Sciences, 10: 242-260.

Hader, D.P. and Worrest, R.C. (1991) Effects of enhanced solar ultra-violet radiation on aquatic ecosystems, Photochemical \&Photobiological Sciences, 53: 717725 .

Halac, S.R., Villafane, V.E., Goncalves, R.J. and Helbling, E.W. (2014) Photochemical responses of three marine phytoplankton species exposed to ultraviolet radiation and increased temperature: role of photo protective mechanisms, Journal of Photochemistry and Photobiology, B141, 217-227.

Helbling, E,W., Barbieri, E.S., Marcoval, M.A., Goncalves, R.J. and Villafane, V.E. (2005) Impact of solar ultraviolet radiation on marine phytoplankton of Patagonia, Argentina, Journal of Photochemistry and Photobiology, 81(4): 807-818.

Holzinger, A. and Lutz, C. (2006) Algae and UV irradiation: Effects on ultra structure and related metabolic functions, Micron, 37(3): 190-207.

Jokiel, P.L. (1980) Solar radiation and coral reef epifauna, Science, 207: 1069-1073.

Karanas, J.J., Van Dyke, K. and Worrest, R.C. (1979) Mid ultraviolet (UV-B) sensitivity of Acartia clausii Giesbrecht (Copepoda), Limnology and Oceanography, 24: 1104-1116.

Kimura, M. and Rodriguez-Amaya, D.B. (2004) Harvest Plus Handbook for Carotenoids Analysis; International food policy research Institute, Washington DC.

Palmisano, A. C., Wharton, R. A., Cronin, S. E. and Des Marais, D.J. (1989) Lipophilic pigments from the benthos of a perennially ice-covered Antarctic lake, Hydrobiologia, 178: 73-80.

Quesada, A. and Vincent, W.F. (1993) Adaptation of Cyanobacteria to the light regime within Antarctic microbial mats, Verhandlungen des Internationalen Verein Limnologie, 25: 123-128. 
Quesada, A., Mouget, J.L. and Vincent, W.F. (1995) Growth of Antartic Cyanobacteria under ultraviolet radiation. UV-A counteracts. Journal of Phycology, 31: 242-248.

Rai, L.C. and Mallick, N. (1998) Algal responses to enhanced Ultraviolet $\mathrm{B}$ radiation. Proceedings of the Indian National Science Academy, B64 (2):125-146.

Sebastian, C., Scheuerlein, R. and Hader, D.P. (1994) Effects of solar and artificial ultraviolet radiation on pigment composition and photosynthesis in three Prorocentrum strains, Journal of Experimental Marine Biology and Ecology, 182: 251-263.

Sinha, R.P. and Hader, D.P. (2002) Life under solar UV radiation in aquatic organisms. Advances in Space Research, 30(6):1547-1556.
Smith, R. Cand Cullen, J. J. (1995) Effect of UV radiation on phytoplankton, Reviews of Geophysics, 33 (1/2): 121 $1-1223$.

Snedecor, G.W. and Cochran, W.G. (1989) Statistical Methods. 8th Ed. Iowa State University Press, Iowa.

Speekmann, C., Bollens, SM. and Avent, S.R. (2000). The effect of ultraviolet radiation on the vertical distribution and mortality of estuarine zooplankton, Journal of Plankton Research, 22 (12): 2325-2350.

Vincent, W.F. and Roy, S. (1993). Solar ultraviolet-B radiation and aquatic primary production: damage, protection, and recovery, Environmental Reviews, 1: 112.

Xue, L., Zhang, Y., Zhang, T., An, L. and Wang, X. (2005). Effects of Enhanced Ultraviolet-B Radiation on Algae and Cyanobacteria, Critical Reviews in Microbiology, 31: 79-89.

\section{تأثثر الأشعة فوق البنفسية "بي" في الثُعاع الثمسي على مجتمع العو الق والبيتا كاروتين تحت ظروف زر اعة ربيان المحيط الهادي الأبيض (Litopenaeus vannamei)

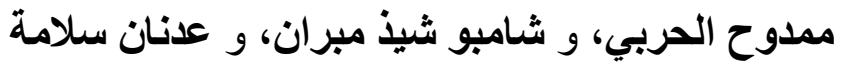 كلية علوم البحار، جامعة الملك عبد العزيز، جدة، المدلكة العربية السعودية لهنية}




\section{Sambhu@kau.edu.sa}

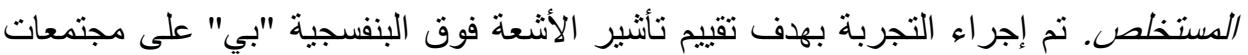

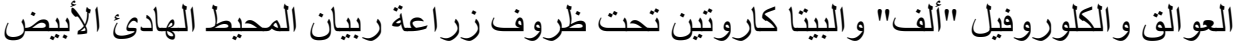
(Litopenaeus vannamei)

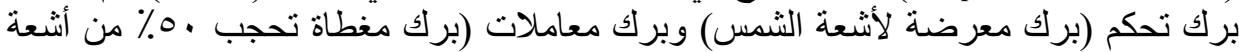

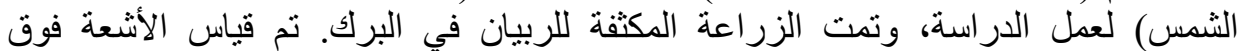

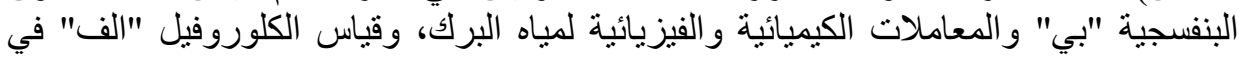

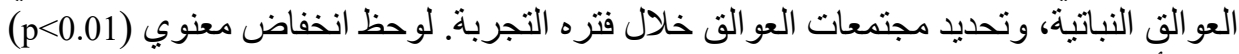

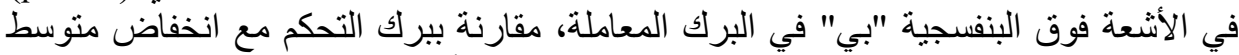

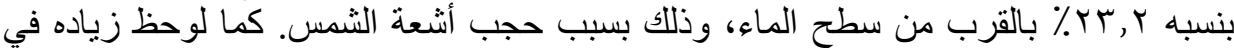

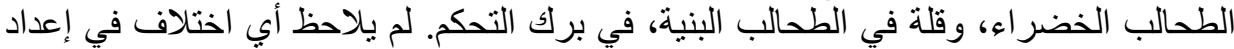

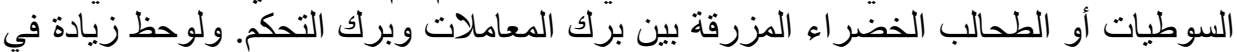

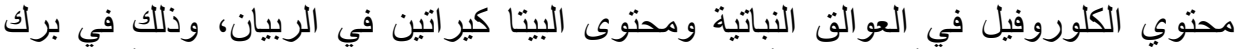

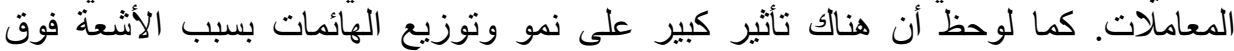

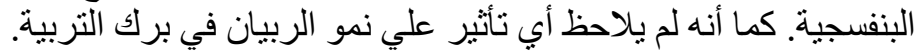

الكلمات الدالة: الأشعة فوق البنفسية "بي"، عو الق، الكلوروفيل "ألف"، البيتا كاروتين، ربيان

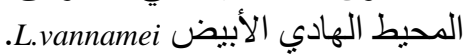

